\title{
肥満小児の食物啫好に関する考察 \\ The Parent's Influence on Obese Children's Food Preferences
}

\author{
門司保健所 (Moji Health Center) \\ 園田 真 人 (Makoto Sonoda) \\ 九州女子大学. (Kyushu Women's University) \\ 江口加代子 (Kayoko Eguchi)
}

Food preferences of the obese child are particular interest because they affect the child's consumption of the foods needed for growthspeed and are also significant in his social development. This study was undertaken to investigate the influence of the food preferences of the parent on those his obese child.

The subjects of this survey were 168 obese children and 189 nonobese children from primary school in Kitakyushu City.

The questionaire was in four parts; (a) social situation (father's occupation and education), (b) nutritional status, (c) father's custom of drinking and smoking, (d) food preference of selected meals. The results as follows;

1) The child's preference of sausage showed the highest percent of like rating, but the categories of carot, fermented soybeans and onion give the lowest percent of like rating.

2) The difference of food preference between the obese child and the nonobese child was not significant.

3) Food preferences of the children (both obese and nonobese) have no relation to his father's custom of drinking and smoking.

4) The relationship between the father's and his partner's preference is more closer than that of the child and his parent, but cannot find out the systematical correlation because the complicated factors combinate together.

\section{は じめ に}

肥満小児の食習慣の特徴として, 明らかに過食がみとめられている。しかも糖質の間食傾向が強く, Taggart ${ }^{11}$ は週末過食 (Weekend hyperphagia), Mayer ${ }^{2)}$ は夜食傾向 (Night eating syndrome) を指商している。入

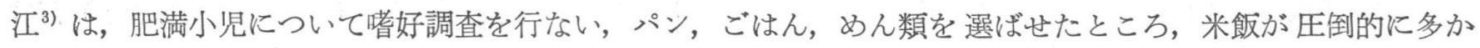
ったという。わたしたちの肥满小児の調査 $(1968)^{4)}$ において, 普通よく食べるものとして，6種類の食品を選 ばせたところ, 肥満小児と対照児の間に, 分布の差はみとめられなかった。栗原 ${ }^{5)}$, 山下 ${ }^{6)}$ (, 肥満者の嗜好調 查を行ない，肥満でないものに比較して，好き程いが著しく少ないといら。

本調査では, 肥満小児に拈ける食物嗜好の親子の関係について調查し, 分布傾向の特異性について分析を行 なったので，その結果を報告する。

\section{調查対象および方法}

調査対象は, 北九州市門司区に所在する19校の小学校児童 13,975 人中より標準体重の $20 \%$ 以をしめすすの 
を肥満として選んだもの168名, これと生活環境がよく似た同じ性, 学年のものを, 一般対照児として選んだ (以下対照児と略記)。

調査方法は, 調査用紙を作成し, 家庭の職業, 父母の学歴, 乳児期の栄養法, 食事を作るものの分布, 食事 時のしつけ, 両親の体位, 父親の飲酒契煙習慣を要因として, にんじん, きゅうり, 牛乳, たまご, なっとう, バナナ，みかん，ソーセージ，とうふ，ねぎ，じゃがいもの11食品について喍好調査を行なった。

調査期日は，昭和44年 5 月である。

\section{調查成績亡考察}

1）食物著好について

11の食品について，好き嫌いを調査し，好きなるのの全例に対する比率をもって嗜好率として比較した。 児童に打ける食物嗜好率は, 第 1 表, 第 1 図にしめすように, 肥満小児と対照児に打いて著しい差異はみら れない。

児童の食品別嗜好率をみると, 全体として, たまご，バナナ，みかん，ソーセージの嗜好率は高く，にんじ ん,なっとう, ねぎの嗜好率は低い。肥満小児の男子では, 対照児よりなっとうの嗜好率が低く, とうふの搘 好率は, 肥満小児の方が高いという結果で, なっとう，とうふの嗜好は異なるが，女子に和ける食品別咾好率 の差は認められない。

父親の食物嗜好率は，第 2 図にしめすように，肥満小児の父親と対照児の父親との間に分布の差異はみられ ない。

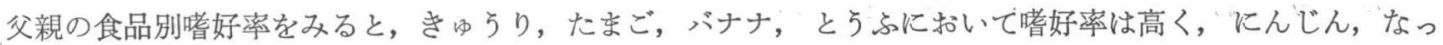
とう，ソーセージの㫮好率は低く，父親のとうふなっとうの嗜好傾向は児童と同じ分布をしめしている。

第 1 表児童の食物嗜好率

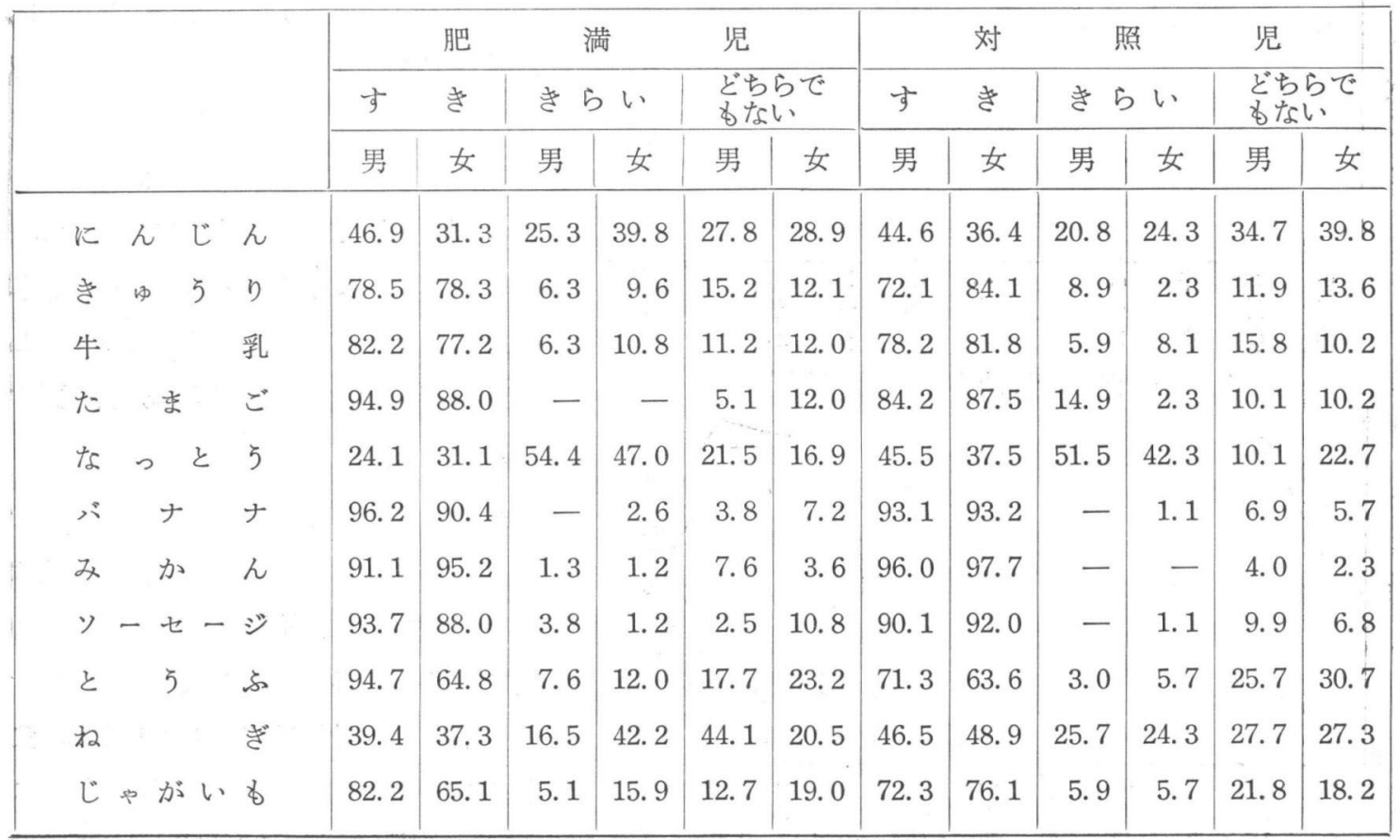



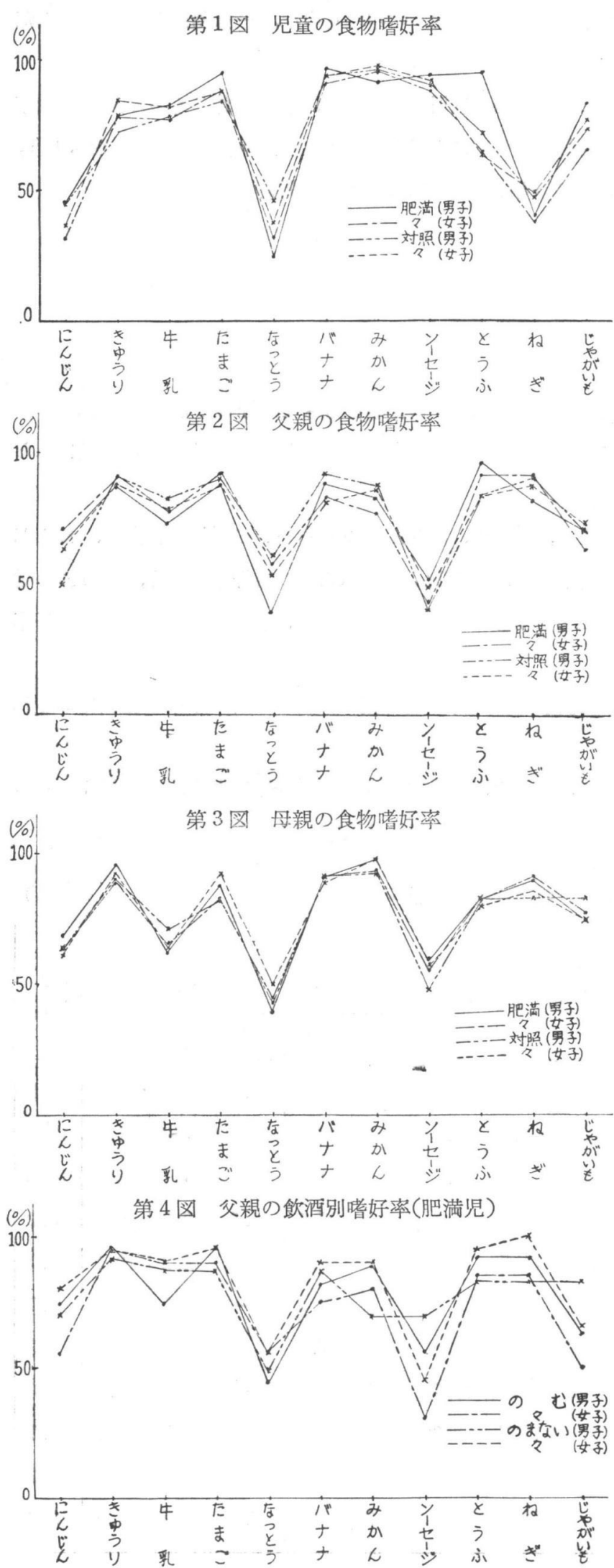

母親の食物嗜好率は, 第 3 図にしめすよ らに，肥満小児と対照児の間に，まったく 分布の差はみられない。

母親の食品別嗜好率を比較すれば，きゅ らり，たまご，バナナ，みかんの暏好率は 高く,なっと5, ソーセージの搘好率は低 い。

以上を要約すれば，肥満小児と対照児の 食物嗜好の差は，ほとんどみられず，それ ぞれの両親の食物嗜好についてもまったく 差はない。

食品別嗜好率は小児では，にんじん，な っとう, ねぎが嬚われ，ソーセージが好ま れているが, 両親においては,なっとうは 共通して嫌われて和り, 子供とは反対にン 一七ージの嗜好率は低く、ねぎの嗜好率は 高いということになる。

2）父親の飲酒, 契煙の影響

父親の飲酒率は, 肥満小児では $25.2 \%$, 対照児では26.5\%であり，両者に差はない。 飲酒習慣と食物嗜好の関係をみると，第 4 , 5 図にしめすように，肥満小览の父親では， 飲酒しないもののじゃがいもの暏好率が高 い傾向にあるが，著明な差はみられない。 対照児において, 飲酒しない父親のと5 ふの搘好率は, 飲酒するものに比較して, 低い傾向にあり，逆にソーセージの㫮好率 は飲酒しないるのが高い傾向をしめすこと は興昧ある成績であり，さらに分析を要す る。

父親の契煙率は，肥満小児では77.9\%で あり，対照児では71.9\%であり両者に差は ない。喫㾞と食物嗜好の関係をみると，と くに嗾好率と喫㾏の関係はなく，児童の食 物嗜好とも無関係である。こころみに，父 親について, 現在の体位を Rohrer 指数に よって, 肥満と非肥満に分け, 飲酒の習慣 
第 5 図 父親の飲酒別啫好率(対照児)

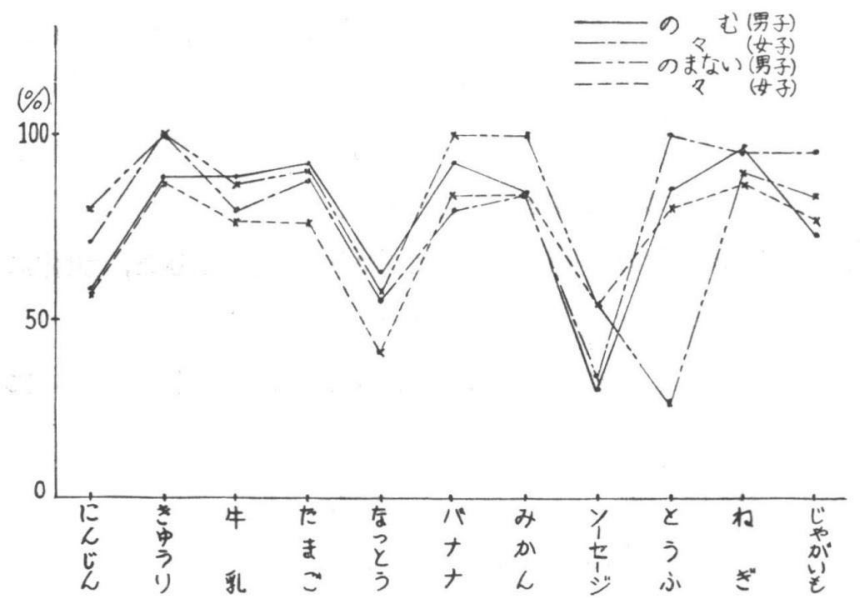

との関係をみると，差はみとめず（ $x^{2}=$ 2. 031)，喫煙の習慣と肥満との関係もみら れなかった $\left(x^{2}=1.001\right) 。$

要約すれば, 父親の飲酒, 契煙の習慣と 父親の食物嗜好は，大体に扣いて関係がな く，児童の食物嗜好とも無関係であるとい える。

3）家庭環境と食物喍好

肥満小児扣よび対照児について, 出生順 位および乳児期の栄養法と食物嗜好率の関 係を比較すれば，まったく差をみとめない。 食事時のたベ方について両親がマナーを

きびしくするかといら要因別に食物嗜好率を比較すれば，肥満小児と対照児の間に分布の差をみとめない。

すなわち, 出生順位, 乳児期の栄湌法, 食事時のしつけとい5因子と食物嗜好は, とくに関係ないといえる。

4）食物嗜好の親子の関係

食物嗜好の親子の関係についての報告は少ないようである。土井 ${ }^{7)}$, 早川 ${ }^{8)}$ は, 食物嗜好の母子の関係を調査 し，母親の食物嗜好は，子供に大きく影響しているという。 Bryan $^{9)}$ は，幼稚園児と父親との食物嗜好を調査 し, 野菜の嗜好に拈いて密接な関係があるという。しかし, 上記の報告は, いずれも片方の親だけの検定であ るので, 結論は尚早であると考党る。

わたしたちは ${ }^{10)}, 280$ 名の幼稚園児について, 牛乳とトマトとい5食品を選び, 夫婦, 親子の間の暂好を調査 し，親子では，母親よりむしろ父親の食物嗜好の影響が大きいことを報告した。

第 2 表 食品別食物嗜好の親子・夫婦相関

\begin{tabular}{|c|c|c|c|c|c|c|c|c|c|}
\hline & & & & 肥 & \multicolumn{2}{|r|}{ 児 } & \multicolumn{2}{|l|}{ 対 } & 児 \\
\hline & & & & 母 と子 & 父と子 & 父と母 & 母 と子 & 父と子 & 父と母 \\
\hline に & h & じ & & 29. $229^{*}$ & 6. $669^{*}$ & 23. $008^{*}$ & $10.592^{*}$ & 14. $402^{*}$ & $24.375^{*}$ \\
\hline き & $\Phi$ & $5 \quad$ & $\eta$ & 2.532 & 4. $596^{*}$ & 5. $970 *$ & 3. 340 & 2. 972 & 0.358 \\
\hline 牛 & & 寽 & 乳 & 7. $702^{*}$ & 0.730 & 0.911 & 1. 544 & 0.381 & 7. 109* \\
\hline た & ま & $\check{c}$ & ご & 4. $309 *$ & 2. 179 & 6. $679 *$ & 0.615 & 2.817 & $20.142^{*}$ \\
\hline な & 0 & と & 5 & 26. $759 *$ & 12. $632^{*}$ & 12. $733^{*}$ & $39.503^{*}$ & 8. $314^{*}$ & 10. $042^{*}$ \\
\hline ハi & ナ & $y$ & ナ & 4. $849 *$ & 10. $248^{*}$ & 14. $622^{*}$ & 8. $357^{*}$ & 21. $979^{*}$ & $10.172^{*}$ \\
\hline み & か & r & ん & $102.935^{*}$ & 5. $229^{*}$ & 0.772 & 0.833 & 0.382 & 9. $336^{*}$ \\
\hline ソ & - 七 & - & ジ & 3. 503 & 0.314 & 28. $491^{*}$ & 2.711 & 3. 221 & $29.041^{*}$ \\
\hline と & 5 & 3 & گ & $9.845^{*}$ & 2. 454 & 9. $474^{*}$ & $16.602^{*}$ & 19. $442^{*}$ & 7. $066^{*}$ \\
\hline ね & & & ぎ & 2.828 & 1. 097 & 7. $351^{*}$ & 12. $461^{*}$ & 2. 578 & 3. 576 \\
\hline じ & ゃ & W & 8 & 4. $730^{*}$ & 0.558 & 9. $316^{*}$ & 1. 001 & 1. 171 & 6. $223^{*}$ \\
\hline
\end{tabular}

注 : 数值は $x^{2}$ test, * 印は有意差をみとめるもの。 
本調査では，夫婦の間拉よび母子，父と子とい5形で分析し，11品目の食品について，第 2 表にしめすよ うに嗜好の関係を調査した。嗜好の一致率をみると, 肥満小児と対照児ともに，父と母の食物嗜好の相関は高 く，11品目のうちで81.8\%をしめしている。

父と子の搘好の一致率は，肥満小児は $45.5 \%$ であり，対照児では $36.4 \%$ と低いが，母と子の一致率は肥満小

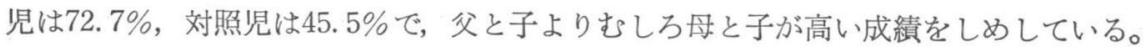

肥満小児と対照児について，食品別の嗜好率を比較し，両親と子の間について搘好の相関をみると，大体に 扣いて肥満小児と刘照児の親子の嗜好の関係は似ている。

食品について嗜好の相関がみられるのは，肥満小児では，にんじん，なっとう， バナナ，みかんであるのに 対し，対照児では，にんじん，なっとう，とうふ，バナナである。

親子の嗜好の相関がみられない食品は, 肥満小児では, わずかソーセージ，ねぎであるのに対し，対照児で は,きゅ5り, 牛乳, たまご, みかん, ソーセージ,じゃがいもに拈いても嗜好の相関がみられない。

すなわち, 本調査に扣いては, 親子よりも夫婦間の搘好の相関傾向は高く, しかも親子の嗜好についてては, 対照児より肥満小児のほうが，より密接であり，とくに父親よりも母親の搘好と関係があるという結果である。 しかし，本調査でみられるように，お互いに複雑に相関しあっているため，肥満小児，対照児の食物嗜好の傾 向を公式的に指摘することができない。今後さらに研究を要する課題である。

両親の体位を肥満と非肥満に分類し，食品別に嗜好の相関を比較したが，極めて複雑化して拈り，食品別の 搘好傾向はみとめられないようである。

総括

わたしたちは, 北九州市門司区の小学校児童から選び出した肥満小児168名と対照児189名について, 11 の食 品について食物嘫好調査を行ない, 夫婦および親子の関係を調査した。

1）小児の食物嗜好をみると，にんじん，なっとう，ねぎが嫝われており，ソーセージは好まれているが， 両親では,きゅうり，たまご，バナナ，とうふが好まれており，子供と反対にソーセージは嫌われている。

2 ）肥満小児と対照児の食物嗜好の傾向は，まったく両者に差がみられない。

3 ）父親の飲酒，喫煙の習慣と食物嗜好との関係は，まったくみられず，児童の食物嗜好とす無関係である。

4 ）肥満小児括よび対照児ともに, 出生順位, 乳児期栄養法, 家庭に括ける食事時のしつけなどの因子と食 物嗜好は無関係である。

5 ）親子の食物喍好よりむしろ夫婦間の嗜好がより密接であるが，複雑にくみあっているため，一定の法則 はみいだしがたい。

文献

1) Taggart, N. : Brit. J. Nutr., 16, 223 (1962) 9) Bryan, M. : J. Am. Diet. Ass., 34, 30 (1958)

2) Mayer, J. : J. Med., 274, 610 (1966)

3）入江英博 : 日本医事新報，2269 (1967)

4）園田真人ほか：日本医師会誌，62，251 (1969)

5）栗原茂実 : 広島大医誌，15，317 (1967)

10）園田真人, 江口加代子 : 栄養学雑誌, 28, 149 (1970)

11) Lowenberg, M. : J. Am. Diet. Ass., 24, 430 (1948)

6）山下文雄 : 治療，48，477（1966）

12) Spencg, B. : J. Am. Diet. Ass., 26, 430(1950)

13) Moore, M. : J. A. M. A. 15, 962 (1962)

7) 土井昌子：武庫川女子大紀要，10，131（1962）

8）早川順子 : 東女医大雑誌，39, 744 (1969)

14) Koller, E. : Psychosomatic Medicine, 18, 121 (1966)

15）園田真人，高橋純子：臨床栄湌，34， 649 (1969) （受付 : 昭和 45 年 2 月 9 日） 